\title{
Influence of bearing surface angle of abutment screw on mechanical stability of joint in the conical seal design implant system
}

\author{
Joo-Hyeun Kim', Jung-Bo Huh, Mi-Jung Yun, Eun-Sook Kang ${ }^{2}$, Jae-Chan Heo ${ }^{3}$, Chang-Mo Jeong ${ }^{1 *}$ \\ 'Department of Prosthodontics, School of Dentistry, Pusan National University, Yangsan, Republic of Korea \\ ${ }^{2}$ Department of Prosthodontics, In-Je University Haeundae Paik Hospital, Busan, Republic of Korea \\ ${ }^{3}$ Osstem Implant Research Center, Busan, Republic of Korea
}

Purpose: This study is to evaluate how different bearing surface angles of abutment screw affect the mechanical stability of the joint in the conical seal design implant system. Materials and Methods: Internal connection type regular implants, two-piece cemented type abutments and tungsten carbide/carbon-coated titanium alloy abutment screws were selected. Titanium alloy screws with conical $\left(45^{\circ}\right)$ and flat $\left(90^{\circ}\right)$ head designs which fit on to abutment were fabricated. The abutments were tightened to implants with $30 \mathrm{Ncm}$ by digital torque gauge. The loading was applied once to the central axis of abutment. The mean axial displacement was measured using micrometer before and after the tightening and loading $(n=5)$. The abutment was tightened to implants with 30 $\mathrm{Ncm}$ and T-shape stainless steel crown was cemented. Then the change in the amount of reverse-torque was measured after the repeated loading to the central axis, and the place $5 \mathrm{~mm}$ away from the central axis. Compressive bending and fatigue strength were measured at the place $5 \mathrm{~mm}$ away from the central axis $(n=5)$. Results: Both groups showed the largest axial displacement when abutment screw tightening and total displacement was greater in the flat head group compared to conical head group $(P<$ 0.05). However, there were no significant differences in reverse torque value, compressive bending and fatigue strength $(P>0.05)$. Conclusion: Within the limitations of this study, the abutment screw head design had no effect on two groups regarding the joint stability, however the conical head design affected the settlement of abutment resulting in the reduced total displacement. (J Dent Rehabil Appl Sci 2014;30(3):206-14)

Key words: implant; abutment screw; settling effect; joint stability; removal torque

\section{서론}

스웨덴 룬트대학의 정형외과 의사인 Brånemark ${ }^{1}$ 은 실 험 과정에서 티타늄 금속이 살아 있는 골 조직에 구조적 으로 결합하여 오랜 기간 거부반응 없이 지속되는 현상 을 발견하였고 이를 “골유착”이라 명명하였다. 이후로 골유착 임플란트는 치과분야에서 성공적인 예후를 보이 며 보편적인 치료방법으로 자리 잡았다. ${ }^{2-5}$

*Correspondence to: Chang-Mo Jeong, DDS, PhD Department of Prosthodontics, School of Dentistry, Pusan National University, 20 Geumo-ro, Mulgeum-eup, Yangsan, 626-770, Republic of Korea Tel: +82-55-360-5130, Fax: +82-55-360-5134, E-mail: cmjeong@pusan.ac.kr Received: June 27, 2014/Last Revision: August 8, 2014/Accepted: August 10, 2014
임플란트 보철치료에서 가장 흔하게 발생되는 기계적 합병증은 지대주 나사의 풀림과 파절이다..$^{6-11}$ 나사풀림 은 부적절한 조임회전력, 기능 시 진동 및 표면침하현상, 전하중의 상실 등의 복합적 이유로 발생하며 임플란트에 가해지는 과부하는 짧은 기간에도 예측 불가한 파절을 일으킬 수 있다. ${ }^{12}$ 나사풀림이나 파절로 인한 합병증은 환자와 의사에게 시간과 비용낭비 그리고 복잡한 치료 를 야기한다. 따라서 이러한 합병증을 줄이기 위해 임플

Copyright@ 2014 The Korean Academy of Stomatognathic Function and Occlusion. (c) It is identical to Creative Commons Non-Commercial License. 
란트와 보철물 구성요소 사이에는 높은 지지용량 $(\mathrm{load}$ bearing capacity), 즉 연결부의 안정성이 요구된다. ${ }^{13}$ 연 결부의 안정성에 영향을 미치는 요소에는 전하중, 지대 주 연결형태, 지대주 나사의 형태, 소재, 및 표면코팅 등 이 있다. ${ }^{14-18}$

최근까지 임플란트 제조사들은 다양한 형태의 임플란 트와 지대주간의 연결 구조를 개발하였다. 지대주 연결 형태는 연결부위에 약간의 공극이 존재하여, 수동적으 로 연결되는 slip fit joint와 연결되는 짝 부품사이에 공 간이 존재하지 않아 조임 효과에 의해 고정되는 friction fit joint로 분류할 수 있다. ${ }^{19,20}$ 전자는 지대주 연결부가 외부로 노출되어 있는 Brånemark system으로 후자는 내 부에 위치하고 연결부가 경사진 ITI와 Astra system으 로 대표된다. Norton ${ }^{21}$ 은 내부 원추형 연결형태 임플란 트가 외부 육각형 연결구조 임플란트에 비해 굽힘력에 더 증가된 저항성을 보이고, 나사 풀림의 빈도가 낮다고 하였다. 이는 내부 원추형 연결형태에서 지대주 체결로 인한 조임회전력이 나사신장 뿐만 아니라 지대주의 쐐 기효과로 전환되고 기능 시 하중이 대부분 경사계면을 통해 전달되어 지대주 나사에 가해지는 부하가 제한되 기 때문이다.

그러나 임상적으로 이러한 연결형태는 지대주의 수직 침하(settle down)가 필연적으로 발생하는 것이 보고되 었다. ${ }^{22-24}$ 침하는 임플란트와 지대주 나사의 나사선, 임 플란트와 지대주의 접촉면, 지대주 나사머리와 지대주 접촉면 등 고정체와 지대주 연결부가 접촉하는 모든 부 위에서 발생 할 수 있다. 이러한 침하로 인해 전하중 상 실 및 나사풀림이 발생할 수 있고 지대주의 위치 차이로 인해 보철물의 부적합 및 교합변화를 야기할 수 있다. ${ }^{25-28}$
Jörnéus 등 ${ }^{11}$ 은 Brånemark 임플란트를 대상으로 보철물 나사의 머리형태가 전하중에 미치는 영향을 연구하였 으며 그 결과 금합금의 평평한 머리를 가진 나사가 원추 형 머리의 나사에 비해 높은 전하중을 보임을 보고하였 다. 하지만 이는 외부 육각형 연결구조 임플란트를 대상 으로 시행한 실험이며 오히려 내부 원추형 연결구조 임 플란트에서 원추형의 지대주나사머리가 연결부 안정성 에 기여할 것이라는 주장이 보고된바 있으나 ${ }^{29}$ 이에 관 한 비교 연구는 미비한 실정이다.

이에 본 연구의 목적은 내부 원추형 연결형태 임플란 트에서 지대주 나사의 형태가 연결부의 기계적 안정성 에 미치는 영향을 알아보기 위해 지대주 나사의 접촉부 좌면각도에 따른 침하량, 풀림 토크, 최대 압축굽힘강도 와 피로강도를 측정 비교하였다.

\section{연구 재료 및 방법}

\section{1. 연구 재료}

본 연구에서는 직경 $4 \mathrm{~mm}$, 길이 $11.5 \mathrm{~mm}$ 원추형 연 결구조 티타늄 임플란트(GS II fixture, Osstem Co. Ltd., Busan, Korea)를 사용하였다. 시멘트 유지형 지대 주(Transfer abutment, Osstem Co. Ltd.), 그리고 티타 늄 합금 코팅된 지대주 나사(EbonyGold screw, Osstem Co. Ltd.)를 사용하였다. 실험을 위해 지대주와 지대주 나사의 접촉부 형태를 $45^{\circ}(\mathrm{CH}$ 군 $)$ 와 $90^{\circ}(\mathrm{FH}$ 군 $)$ 로 제작 하였으며 각도 변경에 따라 형상변화 및 접촉면적 변화 가 발생하였다(Table 1, Fig. 1).

Table 1. Features of implant-abutment system

\begin{tabular}{|c|c|c|c|c|c|}
\hline Group & Implant & Implant diameter & $\begin{array}{c}\text { Implant/abutment } \\
\text { interface }\end{array}$ & Abutment & Abutment screw \\
\hline $\mathrm{CH}$ & $\begin{array}{c}\text { GS II } \\
\text { (Ti grade IV) }\end{array}$ & $4.0 \mathrm{~mm}$ & $\begin{array}{l}11^{\circ} \text { taper } \\
\text { internal hexagon }\end{array}$ & $\begin{array}{c}\text { Transfer } \\
\text { (TiN coated Ti grade V) }\end{array}$ & $\begin{array}{c}\text { Conical head }\left(45^{\circ}\right) \\
\mathrm{WC} / \mathrm{CTa}\end{array}$ \\
\hline $\mathrm{FH}$ & $\begin{array}{c}\text { GS II } \\
(\text { Ti grade IV) }\end{array}$ & $4.0 \mathrm{~mm}$ & $\begin{array}{l}11^{\circ} \text { taper } \\
\text { internal hexagon }\end{array}$ & $\begin{array}{c}\text { Transfer } \\
\text { (TiN coated Ti grade V) }\end{array}$ & $\begin{array}{c}\text { Flat head }\left(90^{\circ}\right) \\
\text { WC } / \mathrm{CTa}\end{array}$ \\
\hline
\end{tabular}

$\mathrm{CH}$, conical head abutment screw; FH, flat head abutment screw; TiN, titanium nitride; WC/CTa, tungsten carbide/carbon-coated titanium alloy. 
A

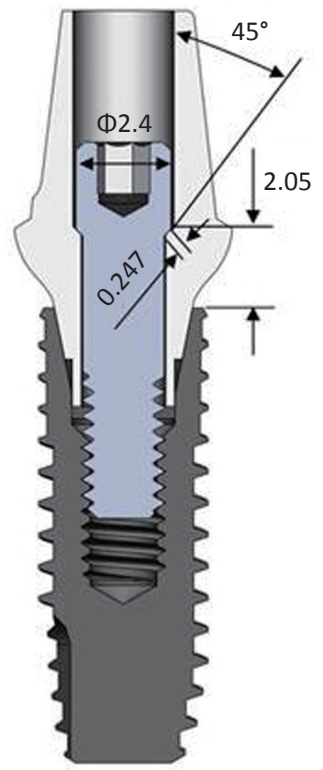

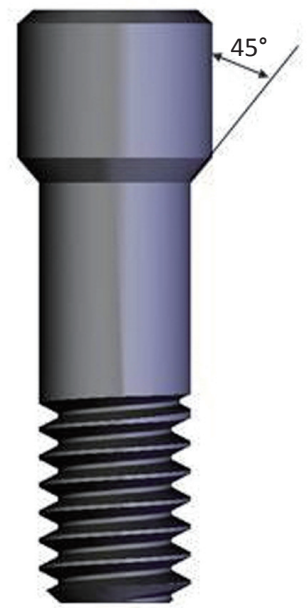

B

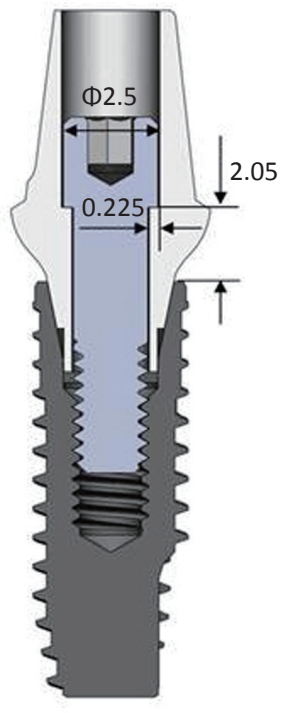

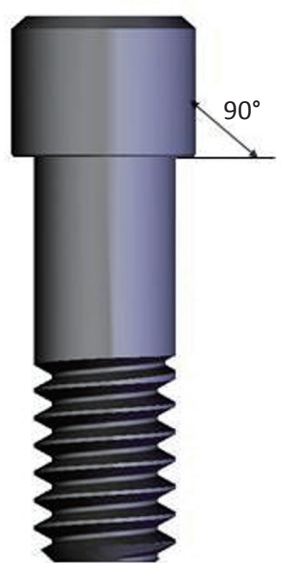

Fig. 1. Sectional views of two groups of implant-abutment assemblies showing interface and attached abutments and screws. (A) Conical head abutment screw of $45^{\circ}$ bearing surface angle, (B) Flat head abutment screw of $90^{\circ}$ bearing surface angle.

\section{2. 연구 방법}

1) 침하량 측정

디지털 토크게이지(MGT12E, MARK-10 Corp., Copiague, $\mathrm{NY}, \mathrm{USA}$ )를 이용하여 최초 $5 \mathrm{Ncm}$ 의 조임회 전력으로 지대주 나사를 이용하여 지대주를 임플란트에 위치시키고 마이크로미터(293-666N, Mitutoyo corp., Kanogawa, Japan)를 사용하여 지대주 최 상방에서 고 정체 바닥까지 길이를 측정하였다. 이후 제조사의 지시 에 따라 $30 \mathrm{Ncm}$ 의 조임회전력으로 지대주를 체결하고
전장을 측정하여 침하량을 기록하였다. 하중 부여에 따 른 침하량을 측정하기 위하여 유압식 피로 시험기(8841 Dynamight $^{\mathrm{TM}}$, Instron Corp., Norwood, MA, USA)의 바닥면에 지대주의 평평한 상부면을 세우고 임플란트 바닥에 수직으로 최대 하중 $500 \mathrm{~N}$ 의 하중을 1 회 가한 후 침하량을 측정하고 이어서 sine형 하중을 $14 \mathrm{~Hz}$ 주기 로 500 회 가한 후 침하량을 다시 측정하였다. 각 군을 대 상으로 새로운 임플란트, 지대주 및 지대주 나사를 이용 하여 5 회 실험하였다(Fig. 2, 3).

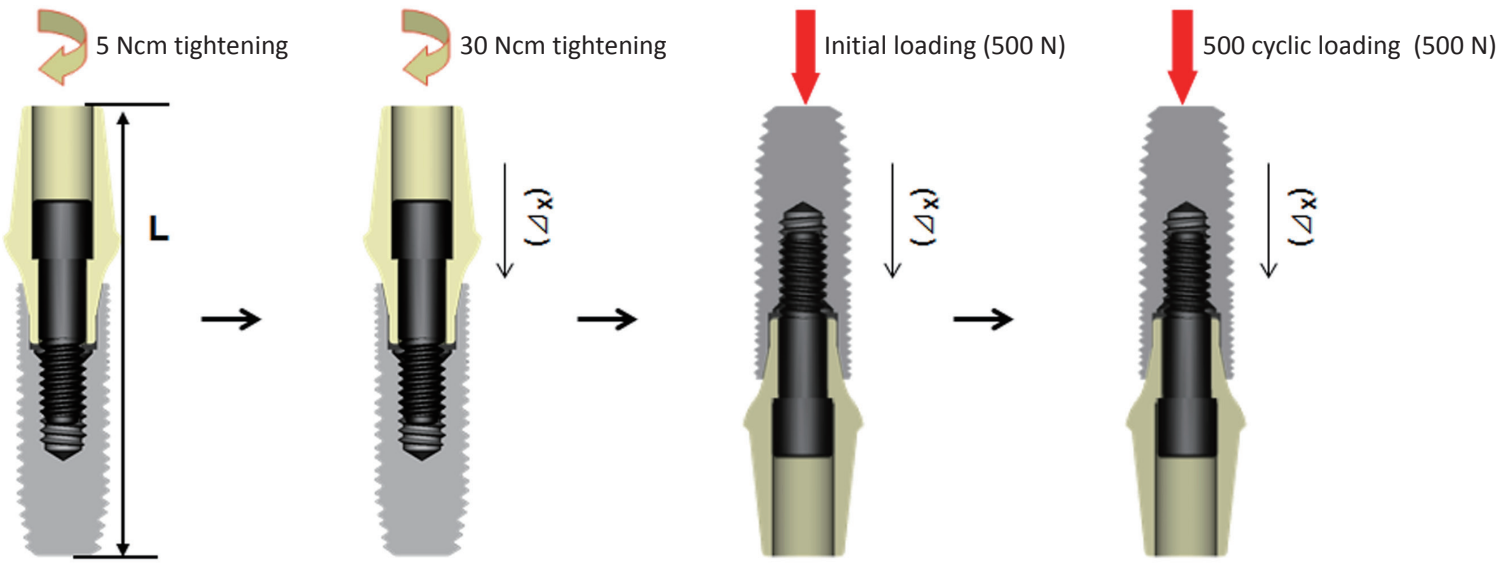

Fig. 2. Schematic diagram for tightening and loading sequence. $\Delta_{\mathrm{X}}=$ axial displacement of the abutment. 


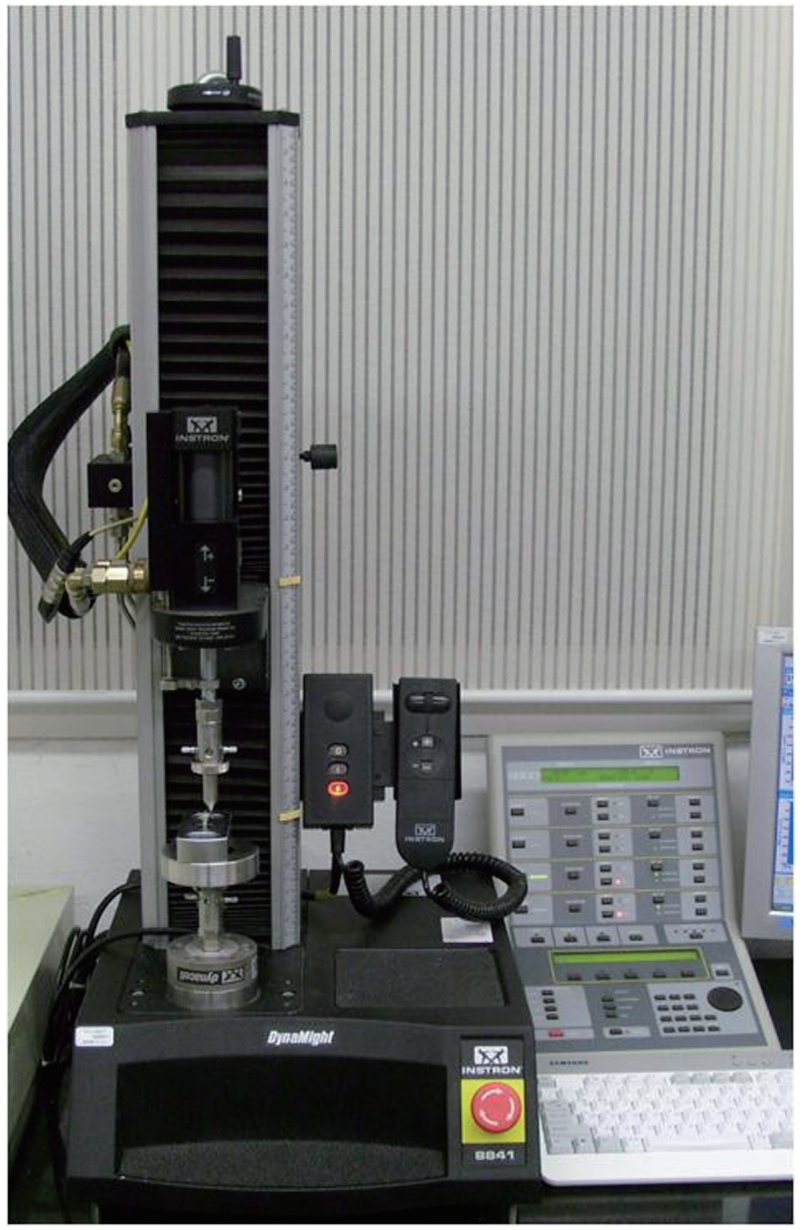

Fig. 3. Loading application instrument (8841 Dynamight $^{\mathrm{TM}}$, Instron Corp., Norwood, MA, USA).

A

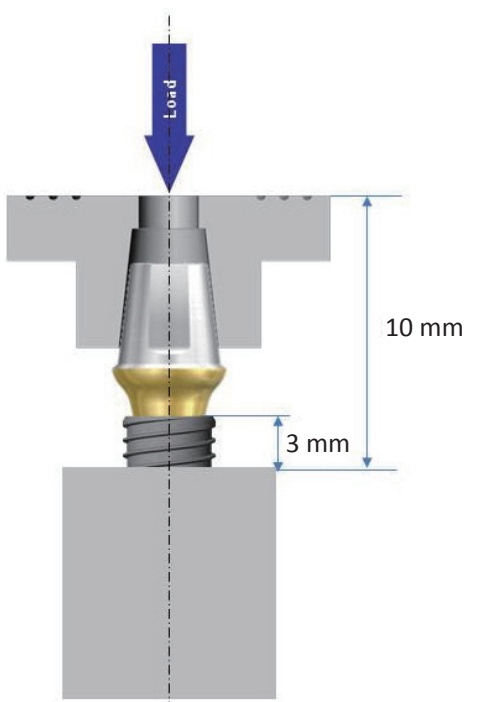

2) 풀림 토크 측정

유압식 피로 시험기에 임플란트 고정체를 $3 \mathrm{~mm}$ 변연 골 흡수된 조건으로 지그에 고정시키고 $30 \mathrm{Ncm}$ 의 조 임회전력으로 지대주를 체결하였다. 지대주 형태에 맞 게 선반 가공된 원통형 스테인리스 스틸 금속관을 레진 시멘트(RelyX ${ }^{\mathrm{TM}}$ U200, 3M ESPE, Seefeld, Germany)로 지대주에 합착하고 고정체 중심축, 그리고 중심축에서 5 $\mathrm{mm}$ 떨어진 금속관 위치에 $500 \mathrm{~N}$ 의 sine형 반복 하중을 $14 \mathrm{~Hz}$ 의 주기로 500 회 가한 후 풀림 토크를 측정하였다. 각 군을 대상으로 새로운 임플란트, 지대주 및 지대주 나사를 사용하여 5 회 실험하였다(Fig. 4).

\section{3) 최대 압축굽힘강도 측정}

풀림 토크 측정과 같은 방법으로 시편을 준비하고 하 중을 고정체 중심축에서 $5 \mathrm{~mm}$ 떨어진 위치에 $1 \mathrm{~mm} /$ $\min$ 속도로 시편이 파절 될 때까지 하중을 가하여 최대 하중을 측정하였다. 각 군을 대상으로 새로운 임플란트, 지대주 및 지대주 나사를 사용하여 5 회 실험하였다.

\section{4) 피로강도 측정}

Fig. 4B와 같은 방법으로 시편을 준비하고 $350 \mathrm{Ncm}$ 의 하중을 $14 \mathrm{~Hz}$ 의 속도로 중심에서 $5 \mathrm{~mm}$ 떨어진 위치 에 시편이 파절 될 때까지 반복 하중을 가하여 하중 부 여 횟수를 측정하였다. 각 군을 대상으로 새로운 임플란 트, 지대주 및 지대주 나사를 사용하여 5 회 실험하였다.

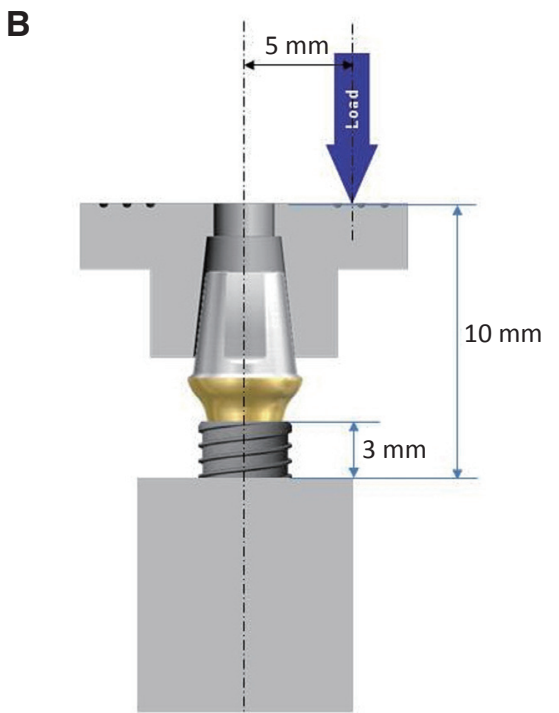

Fig. 4. Diagram of testing setup. Implants were embedded into resin filled cylinder and metal T-bar allowed a force application at center (A) and $5 \mathrm{~mm}$ off-center (B). 


\section{5) 통계 분석}

지대주 나사의 좌면각도에 따른 침하량, 풀림 토크, 최 대 압축굽힘강도와 피로강도의 유의성을 알아보기 위 해 수집된 자료를 SPSS (Release 12.0 Inc., Chicago, IL, $\mathrm{USA}$ )를 이용하여 비모수적 방법인 윌콕슨 부호순위 검 증(Wilcoxon's signed-ranks test)을 실시하였다.

\section{결과}

지대주 나사체결 및 하중 부여 후 지대주 침하량은 Table 2와 Fig. 5에 표시하였다. 지대주 침하량은 두군 모두에서 지대주 체결시 가장 크게 나타났으며 다음으 로 초기하중, 반복하중 순으로 감소하였다. 실험군간 비 교에서 지대주 나사체결에 따른 침하량 및 총 침하량은 $90^{\circ}$ 군에서 크게 나타났으나 초기 하중을 가한 후 침하 량은 $45^{\circ}$ 군에서 크게 측정되었으며 $(P<0.05)$, 반복하중 부여 후 침하량은 두 군간 유의한 차이를 보이지 않았다 $(P>0.05)$.

축방향 반복하중 부여 후 풀림 토크 값은 $45^{\circ}$ 군에서 높게 측정되었고 편심축 반복하중 부여 후 풀림 토크 값 은 $90^{\circ}$ 군에서 높게 측정되었으나, 통계적으로 유의한 차 이를 보이지 않았다 $(P>0.05$, Table 3). 최대 압축굽힘
강도와 피로강도 측정 결과 $45^{\circ}$ 군에서 모두 높게 측정 되었으나 통계적으로 유의한 차이를 보이지 않았다 $(P>$ 0.05, Table 4).

\section{고찰}

본 연구에서는 지대주 연결나사의 좌면각도가 연결 부 기계적 안정성에 미치는 영향을 알아보기 위해 침하 량, 풀림 토크, 최대 압축굽힘강도와 피로강도를 측정하 였다. Dailey 등 $^{24}$ 의 연구에 의하면 원추형 연결형태의 임플란트 시스템에서 조임회전력을 증가시킬수록 지대 주 침하량이 증가하였다. 이는 조임회전력이 지대주 나 사의 신장 즉, 전하중으로 전환되어 원추형 지대주에 압 축력을 가하기 때문이다. $\operatorname{Binon}^{30}$ 은 지대주 나사의 재질 을 변경하거나 지대주 나사의 기하학적 형태나 직경 변 화를 통해 전하중의 증가를 얻을 수 있음을 강조하였다. 두군 모두에서 지대주 체결시 가장 큰 침하량을 보였으 며, 군간 침하량 차이 또한 가장 크게 나타났다. 다음으 로 초기하중 후 침하량이 크게 나타났는데, 두군 간 유의 차이는 있으나 그 크기가 작았고, 반복하중 후 침하량은 미미하였으며 군간 유의차 또한 없는 것으로 나타났다.

실험에서 지대주 체결에 따른 침하량은 $45^{\circ}$ 군이 더 작 은 침하량을 보였다. 이러한 결과는 $45^{\circ}$ 군 지대주 나사
Table 3. Mean values \pm SDs of reverse-torque $(\mathrm{Ncm})$

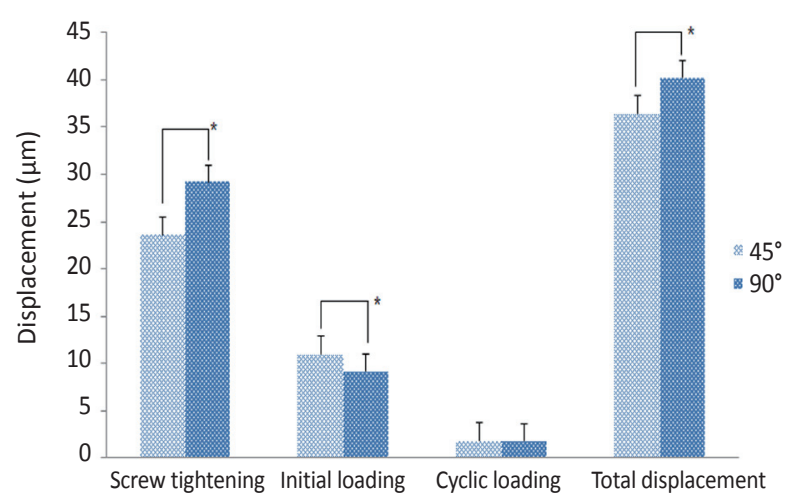

Fig. 5. Comparison of mean displacement ( $\mu \mathrm{m})$.

\begin{tabular}{ccc}
\hline Group & Axial loading & Off-center loading \\
\hline $\mathrm{CH}(\mathrm{n}=5)$ & $5.94 \pm 2.47$ & $5.18 \pm 0.68$ \\
$\mathrm{FH}(\mathrm{n}=5)$ & $5.44 \pm 1.57$ & $5.30 \pm 2.37$ \\
\hline
\end{tabular}

$\mathrm{CH}$, conical head abutment screw; FH, flat head abutment screw.

Table 4. Mean values \pm SDs of compressive bending test and fatigue test

\begin{tabular}{ccc}
\hline Group & $\begin{array}{c}\text { Compressive } \\
\text { bending value }(\mathrm{N})\end{array}$ & $\begin{array}{c}\text { Number of } \\
\text { loading cycle }\end{array}$ \\
\hline $\mathrm{CH}(\mathrm{n}=5)$ & $827.72 \pm 14.86$ & $311473.80 \pm 85664$ \\
$\mathrm{FH}(\mathrm{n}=5)$ & $803.44 \pm 20.30$ & $303995.40 \pm 116631$ \\
\hline $\mathrm{CH}$, conical head abutment screw; FH, flat head abutment screw.
\end{tabular}

Table 2. Mean values \pm SDs of displacements $(\mu \mathrm{m})$

\begin{tabular}{ccccc}
\hline Group & Screw tightening & Initial loading & Cyclic loading & Total displacement \\
\hline $\mathrm{CH}(\mathrm{n}=5)$ & $23.60 \pm 1.95^{*}$ & $11.00 \pm 0.71^{\dagger}$ & $1.80 \pm 1.10$ & $36.40 \pm 2.30$ \\
$\mathrm{FH}(\mathrm{n}=5)$ & $29.20 \pm 1.79^{* *}$ & $9.20 \pm 0.84^{\dagger \dagger}$ & $1.80 \pm 0.84$ & $40.20 \pm 1.30$ \\
\hline
\end{tabular}

Different numbers of superscripts in same column indicate significant difference $(P<0.05)$.

$\mathrm{CH}$, conical head abutment screw; FH, flat head abutment screw. 
에서 경사진 접촉면의 쐐기 효과로 인해 마찰력 증가가 발생하고 조임력 일부를 소실하여 나사 신장에 따른 압 축력이 상대적으로 감소되었기 때문이다. 이에 대한 또 다른 이론적 가능성은 나사머리의 쐐기효과와 그에 따른 지대주의 확장으로 인한 지대주 침하 감소효과이다. ${ }^{29}$ 따 라서 $45^{\circ}$ 군에서 초기하중 후 증가된 침하량은 동일 재 료와 가공정확도를 가정한다면 잔존 침하량이 더 많이 남아있기 때문이라 생각 할 수 있을 것이다. 그러나 최 종 침하량은 $45^{\circ}$ 군이 더 작게 나타났는데 이는 두군 모 두 지대주 체결에 따른 침하량이 하중 부여에 따른 침하 량에 비해 더 크게 발생한 결과가 최종 침하량에 반영되 었기 때문으로 해석된다. 결과적으로 원추형 연결형태 임플란트에서 원추형 지대주 나사를 사용하는 것이 상 대적으로 적은 침하량을 예상할 수 있으나 어떤 나사를 사용하던 간에 보철물 제작 과정에서 교합의 변화 및 부 적합을 줄이기 위해서는 지대주나사를 최종 토크로 반 복 체결해서 충분히 수직침하 시키거나, 더 좋은 방법으 로는 임시수복물을 일정기간 사용 후 다시 나사 조임하 고 지대주 상에서 인상 채득하여 최종 보철물을 만드는 것이 바람직한 방법이 될 것이다.

연결부 지대주의 안정성은 나사조임회전력에 의한 전 하중 ${ }^{14}$ 에 크게 의존하는데 계면에서 마찰력이나 소성 변 형에 의해 에너지가 소실되면 이는 전하중의 소실로 이 어지게 된다. ${ }^{31}$ Ding 등 ${ }^{29}$ 은 ITI 임플란트에서 반복적으 로 조임회전력 적용 시 1-piece solid abutment에 비해 2-piece synOcta solid abutment가 더 증가된 풀림 토크 값을 나타냈으며 원추형 연결 구조는 두 계면간의 마찰 저항 즉, 힘과 마찰계수와 연관되고 접촉 면적은 명백한 결정 요인이 아니라고 보고하였다. 이러한 결과는 원추 형의 지대주 나사가 지대주의 bearing ring에 접촉하면 서 쐐기효과에 의해 나사가 조여질수록 더욱 안착되어 큰 마찰 저항이 발생하고 더 큰 체결력(clamping force) 이 가해지게 된다고 설명하였다.

실험에서 반복하중 후 $45^{\circ}$ 군에서 높은 풀림 토크 값을 기대하였으나 $90^{\circ}$ 군과 유의한 차이를 보이지 않았다. 이 러한 결과는 $45^{\circ}$ 군에서 나사 조임 시 지대주 나사 좌면 부의 마찰저항 증가로 상대적으로 낮은 전하중이 형성 되지만, 나사를 풀 때는 오히려 증가된 마찰저항으로 인 하여 풀림 토크 값이 $90^{\circ}$ 군과 유사한 값을 보였다고 생 각된다.

압축굽힘강도와 피로강도 측정은 임플란트 지대주 연 결 복합체의 파절 강도와 영속성을 실험실 조건에서 시
뮬레이션 할 수 있고 임프란트 연결부 임계영역 설정에 도움을 준다. 압축굽힘강도는 최대 교합력과 연관되고 평균 교합력 피로강도와 연관성이 깊다. Gibbs 등 ${ }^{32}$ 은 자연치열의 평균 최대 교합력은 $720 \mathrm{~N}$ 이고, 평균 저작 력은 271 N이라고 기술하였고, Haraldson 등 ${ }^{33}$ 은 임플 란트 수복물을 조사한 결과 최대 교합력은 $144.4 \mathrm{~N}$ 이며 평균 저작력은 $50.1 \mathrm{~N}$ 이라고 보고하였다. 본 실험은 불 리한 조건에서 시뮬레이션하기 위해 최대 교합력과 평 균 저작력보다 크게 압축굽힘강도 실험에 $500 \mathrm{~N}$ 의 하중 과 피로강도 실험에 $350 \mathrm{~N}$ 의 하중을 부여하였다. 실험 결과 두군 간에 압축굽힘강도와 피로강도에 유의한 차 이가 없는 것으로 나타났다.

Steinebrunner 등 $^{34}$ 은 6 개의 다른 임플란트 지대주 연 결 형태를 대상으로 실험한 결과 피로파절 강도는 연결 부 디자인에 따라 명백한 차이를 보인다고 보고하였다. 이처럼 임플란트 지대주간의 연결부 형태에 반해 상대 적으로 크기가 작은 지대주나사의 머리형태 변화가 기 계적 강도에 미치는 영향은 작다는 것을 알 수 있다. 그 러나 지대주 나사머리의 수직적 위치가 임플란트 내측 경사면에 위치하는 ITI system에서는 지대주 나사의 쐐 기 작용이 지대주를 통해 임플란트 내측 경사면에 작용 하여 안정성이 증가되지만 실험에서 사용된 GS II 임플 란트 시스템은 지대주 나사의 위치가 내측 경사면 상부 에 위치하기 때문에 이러한 효과가 상대적으로 감소될 수 있으므로 이에 대한 심도 깊은 연구가 필요하다고 생 각된다.

이번 연구는 임상 상황과 다소간의 차이가 있으며 오 직 두 가지 형태의 지대주 나사만을 대상으로 실험하였 고 시편 개수 또한 충분하지 않다는 한계를 지닌다. 따 라서 실험의 결과는 지대주 연결나사의 머리 형태가 침 하량과 연결부 기계적 안정성에 미치는 영향을 분석하 는데 기초적인 자료로 해석되어야 할 것이며, 다양한 실 험조건과 임플란트 시스템을 대상으로 한 추가적인 연 구가 필요할 것으로 생각된다.

\section{결론}

본 연구는 내측 원추형 연결 형태 임플란트에서 지대 주 나사머리의 좌면각도가 지대주 침하와 연결부 안정 성에 미치는 영향을 알아보기 위해 지대주 침하량, 풀림 토크, 압축 굽힘 강도와 피로 강도를 측정하여 비교하여 다음과 같은 결과를 얻었다. 
본 실험조건 하에서 원추형 나사머리가 평평한 나사 머리와 비교하여 지대주 체결에 의한 침하량은 작으나 초기 하중 부여에 따른 침하량은 약간 증가된 수치를 보 였으며 총 침하량 값은 작았다 $(P<0.05)$. 반복하중 부 여 후 풀림토크, 압축굽힘강도 그리고 피로강도 실험 결 과 지대주 나사의 형태 차이에 따른 유의한 차이를 보이 지 않았다 $(P>0.05)$. 이러한 결과는 평평한 형태의 나사 머리보다는 원추형태의 나사머리를 갖는 지대주 나사의 사용이 침하량 감소에 약간의 도움이 될 수 있으나, 나 사머리 형태가 연결부의 전체적인 기계적 안정성에 미 치는 영향은 적다는 것을 의미한다. 따라서 기계적 합병 증을 예방하기 위해서는 과부하를 최소화할 수 있는 생 역학적 치료계획, 적절한 보철물 및 치료술식의 선택, 그리고 주기적인 점검이 임상적으로 더 중요한 요소임 이 강조되어야 할 것이다.

\section{References}

1. Brånemark PI, Adell R, Breine U, Hansson BO, Lindström J, Ohlsson A. Intra-osseous anchorage of dental prostheses. I. Experimental studies. Scand J Plast Reconstr Surg 1969;3:81-100.

2. Brånemark PI, Hansson $\mathrm{BO}$, Adell R, Breine U, Lindström J, Hallén O, Ohman A. Osseointegrated implants in the treatment of the edentulous jaw. Experience from a 10-year period. Scand J Plast Reconstr Surg Suppl 1977;16:1-132.

3. Zarb GA, Schmitt A. The longitudinal clinical effectiveness of osseointegrated dental implants: the Toronto study. Part I: surgical results. J Prosthet Dent 1990;63:451-7.

4. Zarb GA, Schmitt A. The longitudinal clinical effectiveness of osseointegrated dental implants: the Toronto study. Part III: problems and complications encountered. J Prosthet Dent 1990;64:185-94.

5. Adell R, Lekholm U, Rockler B, Brånemark PI. A 15 -year study of osseointegrated implants in the treatment of edentulous jaw. Int J Oral Surg 1981; 10:387-416.

6. Johansson G, Palmqvist S. Complications, supplementary treatment, and maintenance in edentulous arches with implant-supported fixed prostheses. Int J Prosthodont 1990;3:89-92.

7. Tolman DE, Laney WR. Tissue-integrated prosthe- sis complications. Int J Oral Maxillofac Implants 1992;7:477-84.

8. Carlson B, Carlsson GE. Prosthodontic complications in osseointegrated dental implant treatment. Int J Oral Maxillofac Implants 1994;9:90-4.

9. Hemmings KW, Schmitt A, Zarb GA. Complications and maintenance requirements for fixed prostheses and overdentures in the edentulous mandible: a 5-year report. Int J Oral Maxillofac Implants 1994;9:191-6.

10. Jemt T, Pattersson P. A 3-year follow-up study on single implant treatment. J Dent 1993;21:203-8.

11. Jörnéus L, Jemt T, Carlsson L. Loads and designs of screw joints for single crowns supported by osseointegrated implants. Int J Oral Maxillofac Implants 1992;7:353-9.

12. Burguete RL, Johns RB, King T, Patterson EA. Tightening characteristics for screwed joints in osseointegrated dental implants. J Prosthet Dent 1994;71:592-9.

13. Taylor TD. Prosthodontic problems and limitations associated with osseointegration. J Prosthet Dent 1998;79:74-8.

14. Khraisat A, Abu-Hammad O, Al-Kayed AM, DarOdeh N. Stability of the implant/abutment joint in a single-tooth external-hexagon implant system: clinical and mechanical review. Clin Implant Dent Relat Res 2004;6:222-9.

15. Kitagawa T, Tanimoto Y, Odaki M, Nemoto K, Aida M. Influence of implant/abutment joint designs on abutment screw loosening in a dental implant system. J Biomed Mater Res B Appl Biomater 2005;75:457-63.

16. Tsuge T, Hagiwara Y. Influence of lateral-oblique cyclic loading on abutment screw loosening of internal and external hexagon implants. Dent Mater J 2009;28:373-81.

17. Khayat PG, Hallage PG, Toledo RA. An investigation of 131 consecutively placed wide screw-vent implants. Int J Oral Maxillofac Implants 2001;16: 827-32.

18. Park JK, Choi JU, Jeon YC, Choi KS, Jeong CM. Effects of abutment screw coating on implant preload. J Prosthodont 2010;19:458-64.

19. Binon PP. Evaluation of three slip fit hexagonal 
implants. Implant Dent 1996;5:235-48.

20. Binon PP. The spline implant: design, engineering, and evaluation. Int J Prosthodont 1996;9:419-33.

21. Norton MR. An in vitro evaluation of the strength of an internal conical interface compared to a butt joint interface in implant design. Clin Oral Implants Res 1997;8:290-8.

22. Bozkaya D, Müftü S. Mechanics of the taper integrated screwed-in (TIS) abutments used in dental implants. J Biomech 2005;38:87-97.

23. Bozkaya D, Müftü S. Mechanics of the tapered interference fit in dental implants. J Biomech 2003;36: 1649-58.

24. Dailey B, Jordan L, Blind O, Tavernier B. Axial displacement of abutments into implants and implant replicas, with the tapered cone-screw internal connection, as a function of tightening torque. Int $\mathrm{J}$ Oral Maxillofac Implants 2009;24:251-6.

25. Jemt T, Book K. Prosthesis misfit and marginal bone loss in osseointegrated implant patients. Int J Oral Maxillofac Implants 1996;11:620-5.

26. Guichet DL, Caputo AA, Choi H, Sorensen JA. Passivity of fit and marginal opening in screw- or cement-retained implant fixed partial denture designs. Int J Oral Maxillofac Implants 2000;15:23946.

27. Herbst D, Nel JC, Driessen CH, Becker PJ. Evaluation of impression accuracy for osseointegrated implant supported superstructures. J Prosthet Dent 2000;83:555-61.

28. Sahin S, Cehreli MC. The significance of passive framework fit in implant prothodontics: current status. Implant Dent 2001;10:85-92.

29. Ding TA, Woody RD, Higginbottom FL, Miller BH. Evaluation of the ITI Morse taper implnat/ abutment design with an internal modification. Int J Oral Maxillofac Implants 2003;18:865-72.

30. Binon PP. Implants and components: entering the new millennium. Int J Oral Maxillofac Implants 2000;15:76-94.

31. Dixon DL, Breeding LC, Sadler JP, McKay ML. Comparison of screw loosening, rotation, and deflection among three implant designs. J Prosthet Dent 1995;74:270-8.

32. Gibbs CH, Mahan PE, Lundeen HC, Brehnan K, Walsh EK, Holbrook WB. Occlusal forces during chewing and swallowing as measured by sound transmission. J Prosthet Dent 1981;46:443-9.

33. Haraldson T, Carlsson GE. Bite force and oral function in patients with osseointegrated oral implants. Scand J Dent Res 1977;85:200-8.

34. Steinebrunner L, Wolfart S, Ludwig K, Kern M. Implant-abutment interface design affects fatigue and fracture strength of implnat. Clin Oral Implants Res 2008;19:1276-84. 


\section{내부 원추형 연결형태 임플란트에서 지대주 나사머리의 좌면각도가 연결부 기계 적 안정성에 미치는 영향}

\section{김주현 ${ }^{1}$, 허중보 ${ }^{1}$, 윤미정 ${ }^{1}$, 강은숙 ${ }^{2}$, 허재찬 $^{3}$, 정창모 ${ }^{1 *}$}

${ }^{1}$ 부산대학교 치의학전문대학원 치과보철학교실, ${ }^{2}$ 인제대학교 해운대백병원 보철과, ${ }^{3}$ 오스템 임플란트 연구소

목적: 내부 원추형 연결형태 임플란트에서 지대주 나사의 좌면각도가 연결부의 기계적 안정성에 미치는 영향을 알아 보기 위함이다.

연구 재료 및 방법 : 원추형 연결구조 티타늄 임플란트와 시멘트 유지형 지대주, 텅스텐 카바이드 코팅된 티타늄 합금 지 대주 나사를 사용하였다. 좌면각도가 $45^{\circ}$ 와 $90^{\circ}$ 를 갖는 지대주와 지대주 나사를 제작하여 $30 \mathrm{Ncm}$ 조임회전력으로 지 대주를 체결한 후 하중을 가하고 체결 및 하중 부여에 따른 침하량을 측정하였다 $(\mathrm{n}=5)$. 유압식 피로시험기에 임플란 트를 고정하고 스테인리스 스틸 금속관을 지대주에 합착하였다. 이 후 반복 하중을 가한 후 풀림토크 변화량을 측정하 고, 압축굽힘강도와 피로강도를 측정하였다 $(\mathrm{n}=5)$.

결과: 지대주 침하량은 지대주나사 체결 시 가장 크게 나타났으며 $(P<0.05)$, 나사체결과 하중부여에 따른 총 침하량은 $45^{\circ}$ 군보다 $90^{\circ}$ 군에서 더 크게 측정되었다 $(P<0.05)$. 반복하중 부여 후 풀림 토크, 그리고 최대 압축굽힘강도와 피로강 도는 통계적으로 유의한 차이를 보이지 않았다 $(P>0.05)$.

결론: 본 실험조건하에서 지대주 나사머리의 원추형 설계가 지대주의 총 침하량을 약간 감소시키는 효과를 나타냈으 나, 연결부의 전체적인 기계적 안정성에 미치는 영향은 크지 않을 것으로 판단된다.

(구강회복응용과학지 2014;30(3):206-14)

주요어: 임플란트; 지대주 나사; 침하량; 연결부 안정성; 풀림토크

*교신저자: 정창모

(626-770) 경남 양산시 물금읍 금오로 20 양산부산대학교 치과병원 보철과

Tel: 055-360-5130 | Fax: 055-360-5134 | E-mail: cmjeong@pusan. ac. kr

접수일: 2014년 6월 27일 | 수정일: 2014년 8월 8일 | 채택일: 2014년 8월 10일 